\title{
DNA-Directed RNA Polymerase III Subunit RPC10
}

National Cancer Institute

\section{Source}

National Cancer Institute. DNA-Directed RNA Polymerase III Subunit RPC10. NCI

Thesaurus. Code C134668.

DNA-directed RNA polymerase III subunit RPC10 (108 aa, $12 \mathrm{kDa}$ ) is encoded by the human POLR3K gene. This protein is involved in innate immunity and small RNA synthesis. 